\title{
QUALITY AND ANTIOXIDANT ACTIVIY OF TOMATO CULTIVATED UNDER DIFFERENT SOURCES AND DOSES OF NITROGEN ${ }^{1}$
}

\author{
JOHN SILVA PORTO ${ }^{2 *}$, TIYOKO NAIR HOJO REBOUÇAS ${ }^{2}$, MARIA OLIMPIA BATISTA MORAES $^{3}$, MARINÊS \\ PEREIRA BOMFIM ${ }^{4}$, ODAIR LACERDA LEMOS ${ }^{2}$, JOSÉ MAGNO QUEIROZ LUZ
}

\begin{abstract}
Tomatoes are an important component of the human diet because they are rich in minerals and antioxidants that sequester free radicals in cells, preventing various disorders that affect human health. Here, we aimed to evaluate the effects of different nitrogen sources and concentrations on antioxidant capacity and physical and chemical quality of tomato fruit. The experiment was conducted in Vitória da Conquista, state of Bahia, Brazil, in the experimental field of Universidade Estadual do Sudoeste da Bahia. The experimental setup included a randomized block design with four replicates in a factorial layout of $3 \times 3+1$ (control), for a total of 40 plots. The three treatments comprised different nitrogen sources (calcium nitrate, urea, and ammonium sulfate), applied in three doses $\left(140,280\right.$, and $\left.420 \mathrm{~kg} \mathrm{ha}^{-1}\right)$. We evaluated firmness, $\mathrm{pH}$, titratable acidity - TA, soluble solid - SS, SS/TA ratio, ascorbic acid, carotenoids, flavonoids, phenolic compounds and DPPH inhibition, were evaluated after samples were harvested. However, increasing concentrations of $\mathrm{N}$ adversely affected the acidity and led to an increase in the SS/TA ratio. Increasing the N concentration also reduced the content of bioactive compounds. excluding carotenoids, which consequently impaired antioxidant activity.
\end{abstract}

Keywords: Solanum lycopersicum L.. Bioactive compounds. Antioxidant capacity. Ammonium. Nitrate.

\section{QUALIDADE E ATIVIDADE ANTIOXIDANTE DE TOMATE CULTIVADO SOB DIFERENTES FONTES E DOSES DE NITROGÊNIO}

\begin{abstract}
RESUMO - O tomate é um importante componente da dieta humana, pois é rico em sais minerais e compostos antioxidante que sequestram os radicais livres presentes nas células do organismo, evitando vários distúrbios na saúde humana. O presente trabalho teve o objetivo de avaliar os efeitos de fontes e doses de nitrogênio sobre a capacidade antioxidante e a qualidade físico-química dos frutos do tomateiro. $\mathrm{O}$ experimento foi realizado na cidade de Vitória da conquista - BA, no campo experimental da Universidade Estadual do Sudoeste da Bahia. $\mathrm{O}$ delineamento experimental utilizado foi em blocos casualizados, com quatro repetições em esquema fatorial $3 \times 3+1$ (testemunha), totalizando 40 parcelas. Os tratamentos foram compostos por três fontes de Nitrogênio (nitrato de cálcio, ureia e sulfato de amônio) e três doses (140, 280 e $420 \mathrm{~kg} \mathrm{ha}^{-1}$ ). Após a colheita foram avaliados os atributos da qualidade do fruto: firmeza, $\mathrm{pH}$, acidez titulável, sólidos solúveis, ratio, ácido ascórbico, DPPH, compostos fenólicos, carotenoides, flavonóides. Os níveis crescentes de N influenciaram negativamente nos conteúdos de acidez titulável, por outro lado, proporcionou aumento na relação SS/AT. Os incrementos de $\mathrm{N}$ também reduziram o conteúdo de compostos bioativos, exceto carotenoide, consequentemente prejudicou a atividade antioxidante.
\end{abstract}

Palavras-chaves: Solanum lycopersicum L.. Compostos bioativos. Capacidade antioxidantes. Amônio. Nitrato.

\footnotetext{
*Corresponding author

${ }^{1}$ Received for publication in $05 / 16 / 2014$; accepted in 05/07/2016.

Paper extracted from the Master's degree dissertation of the first author.

${ }^{2}$ Department of Plant and Animal Science, Universidade Estadual do Sudoeste da Bahia, Vitoria da Conquista, BA, Brazil; jsporto87@yahoo.com.br, tiyoko@uesb.edu.br, odairlacerda@hotmail.com.

${ }^{3}$ Department of health education, Instituto Federal da Bahia, Eunápolis, BA, Brazil; mariaolimpiamoraes@hotmail.com.

${ }^{4}$ Center of Agrifood Science and Technology, Universidade Federal Campina Grande, Pombal, PB, Brazil; mpbfito@gmail.com.

${ }^{5}$ Institute of Agricultural Sciences, Universidade Federal de Uberlândia, Uberlândia, MG, Brazil; jmagno@ufu.br.
} 


\section{INTRODUCTION}

Tomato is one of the most cultivated and consumed vegetables in the world, and the global production of this fruit has doubled in the last 20 years (CARVALHO; PAGLIUCA, 2007). Increasing tomato consumption has proved to be one of the main factors leading to the expansion and development of this crop in many countries, encouraging the sale of fresh product (CASA; EVANGELISTA, 2009).

Tomato fruits are important sources of vitamins and minerals in the human diet, as they are rich in antioxidants and bioactive compounds, which are secondary metabolites produced by plants. Phenolic compounds, ascorbic acid, and lycopene, are examples of bioactive compounds found in tomatoes (ROCHA; SILVA, 2011).

Lycopene is the most abundant antioxidant compound in tomatoes, and it imparts the characteristic red color to the majority of existing tomato cultivars on the market. Lycopene and other bioactive compounds, are responsible for antioxidant activity of tomatoes, which prevents the oxidation of essential molecules caused by free radicals, and contribute significantly to the maintenance of human health, including the prevention of heart disease and prostate cancer.

According to Ferreira et al., (2006), tomato yield was previously the main criterion used to evaluate the efficiency of various farming practices for this crop, while the quality of fruit was not an important criterion. However, due to the emphasis on the importance of healthier foods, attention has recently been focused on the agronomic practices implemented during the production of food in order to develop products with better nutritional and nutraceutical qualities.

Tomato antioxidant components depend on the cultivar, growing conditions, growing season, maturation stages both in production and post harvest, and mineral nutrition (ANZA; RIGA; GARBISU, 2006; JAVANMARDI; KUBOTA, 2006; GUIL-GUERRERO; REBOLLOSOFUENTES, 2009; BÉNARD et al., 2009; ILAHY et al., 2011; BORGUINI et al., 2013).

The mineral nutrition controls the physiological processes of plants, and can influence the amount of some organic and inorganic compounds in the plant (HASSAN et al., 2012). In fruits and vegetables, some authors have observed the effects of nitrogen $(\mathrm{N})$ fertilization on $\mathrm{pH}$, concentration of soluble solids, titratable acidity, and antioxidant activity, as well as vitamin $\mathrm{C}$ content, antioxidant compounds, and nitrate content (WARNER; ZHANG; HAO, 2004; HEEB et al., 2005; TOOR; SAVAGE; HEEB, 2006; KOPSELL; KOPSELL, 2006; KEMAL et al., 2007).

In relation to nitrogen $(\mathrm{N})$ uptake in plants, it has been shown that plants can absorb both inorganic ammonium ions $\left(\mathrm{N}-\mathrm{NH}_{4}{ }^{+}\right)$and nitrate $\left(\mathrm{N}-\mathrm{NO}_{3}{ }^{-}\right)$. Some studies have shown that the application of high levels of $\mathrm{N}-\mathrm{NH}_{4}{ }^{+}$and low levels of $\mathrm{N}^{-\mathrm{NO}_{3}}{ }^{-}$improves fruit quality (MARINO et al., 2001; FLORES et al., 2003). Differences in the supply and availability of nutrients in various fertilizers can affect the production of secondary metabolites (TOOR; SAVAGE; HEEB, 2006).

Since color, flavor, and nutraceutical quality of tomatoes may also depend on its antioxidant components, new perspectives on the factors that can affect its composition could aid in clearly defining the quality of tomato (BÉNARD et al., 2009). There are only a few studies on the impact of $\mathrm{N}$ supply on the antioxidant content of tomato (DUMAS et al., 2003; TOOR; SAVAGE; HEEB, 2006; BÉNARD et al., 2009), and more data on the effects of this element is needed.

Studies on leaves have shown that the supply of $\mathrm{N}$ dramatically affects primary and secondary metabolism (FRITZ et al., 2006; HASSAN et al., 2012). Furthermore, Fritz et al. (2006), found that phenolic compounds in tomato leaves increased in response to a low supply of $\mathrm{N}$; however, significant variation was observed in tomato fruits (BÉNARD et al., 2009). A decrease in tomato ascorbic acid content was reported by Dumas et al., (2003), when the supply of $\mathrm{N}$ increased. Conversely, $\beta$-carotene content increased along with increasing $\mathrm{N}$ supply; nevertheless, the impact of $\mathrm{N}$ supply on lycopene content is more controversial (DUMAS et al. 2003; BÉNARD et al., 2009). The N supply can affect the primary and secondary metabolism of the fruit and may also affect plant development, causing changes in the irradiation of fruit, hence, their metabolism, reducing ascorbic acid content under conditions of high levels of N (DUMAS et al., (2003).

There is limited information on the effect of different sources of $\mathrm{N}$ fertilizers on the antioxidant compounds and antioxidant activity of tomatoes. The available data on the mineral nutrition in tomatoes that influence antioxidants are insufficient and/or not very reliable or, in some cases, not relevant, in the present study, we aimed to evaluate the effects of $\mathrm{N}$ sources and dosage on bioactive compounds, antioxidant activity and the physical and chemical characteristics of tomato fruits.

\section{MATERIAL AND METHODS}

The experiment was conducted in the city of Vitória da Conquista, Brazil (Latitude 14 ${ }^{\circ} 53^{\prime} \mathrm{S}$ and Longitude $40^{\circ} 48^{\prime} \mathrm{W}$ ), in the experimental field of the Universidade Estadual do Sudoeste da Bahia, between October 2012 and March 2013, in LATOSOL - Red-Yellow alic, using the tomato hybrid, Silvetty, at a spacing of 1,2 $\times 0,6 \mathrm{~m}$.

The correction for soil preparation was made using 1.3 ton $\mathrm{ha}^{-1}$ magnesium and calcium silicate, 
based on the results of previous soil analyses (Table 1), increasing the base saturation to $70 \%$. The other nutrients were also applied according to the results of soil analysis; the following dosages were applied: $270 \mathrm{~kg} \mathrm{ha}^{-1} \mathrm{P}_{2} \mathrm{O}_{5}, 450 \mathrm{~kg} \mathrm{ha}^{-1} \mathrm{~K}, 7.61 \mathrm{~kg} \mathrm{ha}^{-1}$ $\mathrm{Ca}, 3.75 \mathrm{~kg} \mathrm{ha}^{-1} \mathrm{Mg}, 0.6 \mathrm{~kg} \mathrm{ha}^{-1} \mathrm{Cu}, 0.54 \mathrm{~kg} \mathrm{ha}^{-1} \mathrm{~B}$, $0.2 \mathrm{~kg} \mathrm{ha}^{-1} \mathrm{Fe}, 0.3 \mathrm{~kg} \mathrm{ha}^{-1} \mathrm{Zn}$ and $0.2 \mathrm{~kg} \mathrm{ha}^{-1} \mathrm{Mo}$.

The experimental design included a randomized block with four replicates in a factorial
$3 \times 3+1$ (control), totaling 40 plots. The treatments varied among three sources of $\mathrm{N}$ (calcium nitrate, urea, and ammonium sulfate) administered at three doses $\left(140,280\right.$, and $\left.420 \mathrm{~kg} \mathrm{ha}^{-1}\right)$. Each plot corresponded to 44 plants arranged in 4 rows of 11 plants, and only 7 plants from the central lines of the plot were considered useful. The treatments began two weeks after transplanting and were applied weekly until the $9^{\text {th }}$ week.

Table 1. Soil analysis results at the site surveyed experimental area.

\begin{tabular}{|c|c|c|c|c|c|c|c|c|c|c|c|c|c|c|}
\hline $\mathrm{pH}$ & $\mathrm{K}$ & $\mathrm{Ca}$ & $\mathrm{Mg}$ & $\mathrm{Al}$ & $\mathrm{Na}$ & $\mathrm{T}$ & $\mathrm{H}+\mathrm{Al}$ & V & MO & $\mathrm{P}$ & $\mathrm{Fe}$ & $\mathrm{Zn}$ & $\mathrm{Cu}$ & $\mathrm{Mn}$ \\
\hline & & ----- & 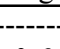 & $\mathrm{nol} \mathrm{d}$ & & & & & b--- & ---- & $-\mathrm{mg}$ & ----- & & \\
\hline 5.7 & 0.26 & 1.6 & 0.6 & 0.3 & 0.04 & 5.4 & 2.9 & 46 & 2.8 & 3 & 85 & 1.3 & 1.0 & 64 \\
\hline
\end{tabular}

Extractor (P), Mehlich-1.

A drip irrigation system was used in addition to other practices, such as hilling (30 days after transplanting [DAT]) and sprouting (beginning at 40 DAT). Two stems per plant were maintained and plant health treatments were performed when necessary.

The harvest started at 110 days after sowing and lasted for five weeks, by collecting only the fruits that reached market ripeness, and were green in color with pink spots. After harvesting, the quality attributes of the fruit were evaluated, including firmness, $\mathrm{pH}$, soluble solids (SS), titratable acidity (TA), SS/TA ratio, ascorbic acid, phenolic compounds, carotenoids, flavonoids, and total antioxidant activity.

For these experiments, four fruits obtained from parcels sent to the laboratory were used. The containers were cleaned and firmness was assessed using a digital texturometer. Immediately after that, the fruits were crushed and a sample of $20 \mathrm{~g}$ was taken for chemical analysis. $\mathrm{pH}$ was measured using a digital $\mathrm{pH}$ meter, $\mathrm{SS}$ content was determined using a digital refractometer at $26{ }^{\circ} \mathrm{C}$, titratable acidity was determined by titrating $0.05 \mathrm{M} \mathrm{NaOH}$ solution (AOAC, 1997), and the SS/TA ratio was obtained by dividing the values of soluble solids by the titratable acidity.

Ascorbic acid content was determined after titration with a $0.5 \%$ Tillman's solution (STROHECKER; HENNING, 1967). The other bioactive compounds were determined by spectrophotometry. Specifically, total carotenoids, determined by the method proposed by Nagata and Yamashita (1992) with modifications, and flavonoids were quantified according to the methodology described by Awad et al (2000). The total concentration of phenolics was determined according to the procedure proposed by Wettasinghe and Shahidi (1999), using the Folin-Ciocauteau method and antioxidant activity quantified by $\alpha$, $\alpha$-diphenyl- $\beta$-picrylhydrazyl (DPPH) free radical scavenging method (BONDET; BRAND-WILLIAMS; BERSET, 1997), and the extracts were obtained using $5 \mathrm{~g}$ of the sample mixture with $15 \mathrm{ml}$ of $80 \%$ ethanol (BRAND-WILLIAMS; CUVELIER; BERSET, 1995).

The data were submitted to analysis of variance polynomial regression, and average relationships compared using the Tukey's test at 5\% probability using statistical software Sisvar ${ }^{\circledR}$, version 5.1 (FERREIRA, 2011).

\section{RESULTS AND DISCUSSION}

The influence of $\mathrm{N}$ fertilization on the quality of the tomato hybrid Silvetty is presented in Table 2. The firmness of the fruit was not significantly affected by different levels or sources of N. Warner, Zhang and Hao (2004), reported similar results when they evaluated the influence of different doses of $\mathrm{N}$ on the commercial quality of the tomato fruit in the cultivars CC337, H9230, H9492, and H9553. Heeb et al., (2005) evaluated different forms of $\mathrm{N}\left(\mathrm{N}-\mathrm{NH}_{4}{ }^{+}\right.$ and $\mathrm{N}-\mathrm{NO}_{3}$ ) in the cultivar "Armada", although both had mean values of 2.85 and $6.9 \mathrm{~kg} \mathrm{~cm}^{-2}$, respectively, which were higher than those reported in the present study $\left(2.28 \mathrm{~kg} \mathrm{~cm}^{-2}\right)$. This difference can be attributed to the advanced stage of ripeness of the tomatoes used for evaluation, while in the previous study mentioned above, the fruits assessed were at the commercially acceptable ripeness stage. 
Table 2. Summary of analysis of variance and average of firmness, $\mathrm{pH}$, titratable acidity (TA), and soluble solids (SS), and $\mathrm{SS} / \mathrm{TA}$ ratio of tomato fruits depending on nitrogen $(\mathrm{N})$ fertilization at the site.

\begin{tabular}{|c|c|c|c|c|c|c|}
\hline SV & GL & Firmness & $\mathrm{pH}$ & TA & SS & $\mathrm{SS} / \mathrm{TA}$ \\
\hline & & & - & --Mean Square & ---------------- & ------------- \\
\hline Block & 3 & $0.01654^{\mathrm{ns}}$ & $0.26347^{*}$ & $0.00277^{*}$ & $4.31097 *$ & $4.32862 *$ \\
\hline Source & 2 & $17.14121^{\mathrm{ns}}$ & $0.03482 *$ & $0.00083^{\mathrm{ns}}$ & $0.65224^{\mathrm{ns}}$ & $0.76136^{\mathrm{ns}}$ \\
\hline Doses & 3 & $32.39265^{\text {ns }}$ & $0.01989^{\mathrm{ns}}$ & $0.02601 *$ & $0.309583^{\mathrm{ns}}$ & $3.92705^{\mathrm{ns}}$ \\
\hline$S \times D$ & 6 & $22.01873^{\text {ns }}$ & $0.01378^{\mathrm{ns}}$ & $0.01732^{\mathrm{ns}}$ & $0.175573^{\text {ns }}$ & $1.64436^{\mathrm{ns}}$ \\
\hline Error & 33 & 13.79294 & 0.00948 & 0.00484 & 0.255704 & 1.43720 \\
\hline \multirow[t]{2}{*}{ CV (\%) } & & 25.56 & 2.29 & 9.4 & 17.31 & 9.08 \\
\hline & & $\mathrm{kg} \mathrm{cm}^{-2}$ & U & $\%$ Citric acid & ${ }^{\circ}$ Brix & $\mathrm{U}$ \\
\hline Calcium Nitrate & & $1.38 \mathrm{a}$ & $4.20 \mathrm{~b}$ & $0.395 \mathrm{a}$ & $4.31 \mathrm{a}$ & $10.69 \mathrm{a}$ \\
\hline Ammonium Sulfate & & $1.38 \mathrm{a}$ & $4.27 \mathrm{ab}$ & $0.396 \mathrm{a}$ & $4.10 \mathrm{a}$ & $10.31 \mathrm{a}$ \\
\hline Urea & & $1.38 \mathrm{a}$ & $4.29 \mathrm{a}$ & $0.398 \mathrm{a}$ & $4.19 \mathrm{a}$ & $11.69 \mathrm{a}$ \\
\hline DMS & & 0.09 & 0.08 & 0.03 & 0.21 & 1.07 \\
\hline
\end{tabular}

$*=$ Significant $(\mathrm{P}<0.05)$ by the $\mathrm{F}$ test.

ns = Not significant.

Averages followed by the same letters on the column indicate that the values do not differ according to the Tukey's test $(\mathrm{P}<0.05)$

Pectic substances present in the cell walls of plants are structures that contribute to the firmness of fruit (SCHWARTZ et al., 2010) and are found in different forms. The protopectin, a water insoluble form of pectic substances, undergoes transformation to pectin during fruit maturation, which by enzymatic action, is first solubilized and then completely degraded when the fruit is ripe, leading to a change in firmness (OLIVEIRA et al., 2006).

The $\mathrm{pH}$ values of the tomato fruit pulp are shown in Table 2, and a lower average was obtained when using calcium nitrate compared with urea. It is possible that larger amounts of reserve carbohydrates were transformed into organic acids and concentrated in vegetable and fruit tissue, leading to a reduction of $\mathrm{NO}_{3}{ }^{-}$and lower rates of photosynthesis in plants treated with calcium nitrate, ultimately affecting the $\mathrm{pH}$. Consequently, the $\mathrm{pH}$ of tomatoes produced using calcium nitrate was lower (BRITTO; KRONZUCKER, 2005).

There were no significant effects of different $\mathrm{N}$ sources on the acid content of the tomato pulp (Table 2); however, a reduction in acidity values (from $0.400 \%$ to $0.350 \%$ ) of citric acid was observed with an increase in $\mathrm{N}$ concentration from 0 to $420 \mathrm{~kg}$ $\mathrm{ha}^{-1}$ (Figure 1). According to Jones Junior (1999), the increase in $\mathrm{N}$ levels negatively affected the quality of fruit, because the high acidity influences the flavor of the tomato.

Although the mean values of acidity were similar to the results of Ferreira et al., (2006), which found $0.389 \%$ of citric acid in tomato fruit (cv. Santa Cruz), in this study, these values did not change with increasing doses of N. According to Bénard et al., (2009), $\mathrm{N}$ fertilization can affect total titratable acidity, contributing to the reduction of its content in tomato fruits.

The different sources and doses of $\mathrm{N}$ did not significantly influence the content of soluble solids in tomato pulp (Table 2). The results presented here are in agreement with the previous findings from Toor, Savage and Heeb (2006), who studied the effects of different $\mathrm{N}$ sources on the quality of the tomato cv. Armada, and did not identify significant differences in the soluble solid content.

Further corroborating this study. Warner, Zhang and Hao, (2004) found that the amount of soluble solids was not affected by different concentrations of $\mathrm{N}$, when they tested doses ranging from 0 to $200 \mathrm{~kg} \mathrm{ha}^{-1}$ of $\mathrm{N}$ in tomatoes for industry. The average content of soluble solids was higher (5.8 ${ }^{\circ}$ Brix) than the average values found in this study (4.20 ${ }^{\circ}$ Brix). On the contrary, Ferreira et al., (2006) reported mean values of $3.93{ }^{\circ} \mathrm{Brix}$, lower than those found here, although they also did not change with increasing doses of $\mathrm{N}$.

No significant differences among the SS/TA ratios were identified using different $\mathrm{N}$ sources (Table 2). However, an increased SS/TA ratio was previously observed in tomato (cv. Armada), when a higher proportion of $\mathrm{N}-\mathrm{NH}_{4}{ }^{+}$in the nutrient solution was used compared to $\mathrm{N}-\mathrm{NO}_{3}$ (HEEB et al., 2005).

Despite the lack of significant difference $(\mathrm{P}<0.05)$ observed in the analysis of variance regarding the dose of $\mathrm{N}$ used, there was a tendency for this ratio to increase with greater $\mathrm{N}$ doses compared to the control (Figure 1B). Kobryn and Hallmann (2005) reported average increases in the $\mathrm{SS} / \mathrm{TA}$ ratio in fruits of three tomato cultivars (Cunero, Tradiro, and Favorita) ranging from 9.95 to 12.54, when the $\mathrm{N}$ dose increased from 140 to 210 $\mathrm{kg} \mathrm{ha}{ }^{-1}$. However, an increase in this ratio with a reduction of $\mathrm{N}$ dose in nutrient solution has also been reported (BÉNARD et al., 2009).

In this study, reducing the titratable acidity values might have enabled the increase in the ratio along with the increase in $\mathrm{N}$ levels. 

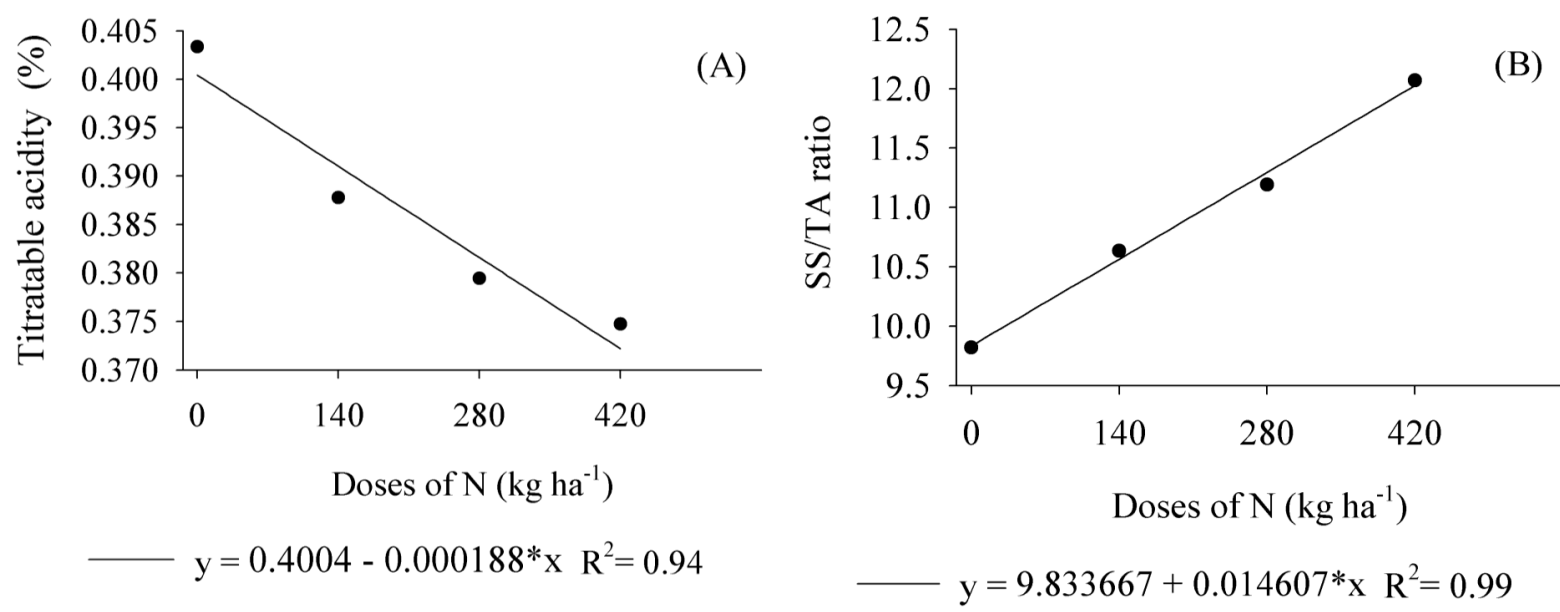

Figure 1. Values of titratable acidity (A) and SS/TA ratio (B) in function of doses of nitrogen N.

The ascorbic acid content in Silvetty tomatoes decreased with an increase in $\mathrm{N}$ concentration, starting $140 \mathrm{~kg} \mathrm{ha}^{-1}$ (Figure 2), only when ammonium sulfate was used. In regard to urea, there was a linear trend in the reduction of ascorbic acid content with the addition of $\mathrm{N}$. Other authors have also reported a negative relationship between the content of ascorbic acid in tomato fruit and an increase in N. Bénard et al., (2009) found that the reduction of $\mathrm{N}$ levels impacts the content of ascorbic acid, causing a slight increase from $11 \%$ to $29 \%$ and corroborating the results presented here, in instances when $\mathrm{N}$ doses used were higher than $140 \mathrm{~kg} \mathrm{ha}^{-1}$. Simone et al., (2007) observed a decrease of $25 \%$ in the ascorbic acid content, when the $\mathrm{N}$ supply increased from 0 to $392 \mathrm{~kg} \mathrm{ha}^{-1}$.

Table 3. Summary of analysis of variance and average of ascorbic acid (AA), antioxidant activity (DPPH), phenolic compounds (FC), carotenoids, and flavonoids in relation to $\mathrm{N}$ fertilization at the study site.

\begin{tabular}{|c|c|c|c|c|c|c|}
\hline SV & GL & AA & Carotenoids & Flavonoids & $\mathrm{FC}$ & DPPH \\
\hline & & & \multicolumn{4}{|c|}{---------------------------------Mean Squares------------------------------- } \\
\hline Block & 3 & $69.9842 *$ & $377.3839 *$ & $29.8865^{\text {ns }}$ & $67.1212 *$ & $655.5220^{*}$ \\
\hline Sources & 2 & $2.7375^{\text {ns }}$ & $81.7301^{\mathrm{ns}}$ & $33.7434^{\mathrm{ns}}$ & $1767.0322 *$ & $55.9489^{\mathrm{ns}}$ \\
\hline Doses & 3 & $4.0604^{\mathrm{ns}}$ & $354.2207^{*}$ & $308.7035^{*}$ & $113.4002 *$ & $1374.5456 *$ \\
\hline$S \times D$ & 6 & $8.2138^{*}$ & $205.5056^{\mathrm{ns}}$ & $32.2277^{\mathrm{ns}}$ & $3.1042^{\mathrm{ns}}$ & $24.6805^{\text {ns }}$ \\
\hline Error & 33 & 2.731249 & 86.1162 & 34.7321 & 7.0285 & $125.6624^{\mathrm{ns}}$ \\
\hline CV (\%) & & & 17.31 & 36.75 & 3.68 & 21.14 \\
\hline & & $\mathrm{mg} 100 \mathrm{~g}^{-1}$ & $\mathrm{mg} 100 \mathrm{~g}^{-1}$ & $\mathrm{mg} 100 \mathrm{~g}^{-1}$ & mg $100 \mathrm{~g}^{-1} \mathrm{GAE}$ & $\%$ inhibition \\
\hline $\begin{array}{l}\text { Calcuum } \\
\text { Nitrate }\end{array}$ & & $14.13 \mathrm{a}$ & $4.12 \mathrm{a}$ & $14.88 \mathrm{a}$ & $82.56 \mathrm{a}$ & $55.18 \mathrm{a}$ \\
\hline $\begin{array}{l}\text { Ammonium } \\
\text { Sulfate }\end{array}$ & & $13.88 \mathrm{a}$ & $3.67 \mathrm{a}$ & $15.56 \mathrm{a}$ & $72.18 \mathrm{~b}$ & $51.96 \mathrm{a}$ \\
\hline Urea & & $13.94 \mathrm{a}$ & $3.91 \mathrm{a}$ & $17.66 \mathrm{a}$ & $61.54 \mathrm{c}$ & $51.93 \mathrm{a}$ \\
\hline SMD & & 1.38 & 8.05 & 5.11 & 2.30 & 9.72 \\
\hline
\end{tabular}

*= Significant $(\mathrm{P}<0.05)$ by the $\mathrm{F}$ test;

${ }^{\mathrm{ns}}=$ No significant;

Averages followed by same letters on the column indicate that the values do not differ according to the Tukey's test $(\mathrm{P}<0.05)$.

Dumas et al., (2003) found that exposure of the fruit to sunlight favored the accumulation of ascorbic acid content in the pulp. However, high doses of $\mathrm{N}$ lead to shoot biomass production, thus, the leaves shade the fruit and reduce the ascorbic acid content produced (TOOR; SAVAGE; HEEB, 2006). This hypothesis is supported since the verified values of shoot biomass were 123.75 and $175.75 \mathrm{~g}$ in the control at a dose of $420 \mathrm{~kg} \mathrm{ha}^{-1}$, respectively.

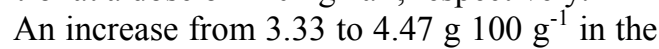

carotenoid content (Figure 3) was found when doses of $\mathrm{N}$ were elevated from 0 to $420 \mathrm{~kg} \mathrm{ha}{ }^{-1}$. Corroborating the results presented here, Bénard et al., (2009) found a reduction in lycopene content according to the reduction in the supply of $\mathrm{N}$. According to Graziani et al., (2003), 80-90\% of the total carotenoids present in the tomato are in the form of lycopene and present in the peel and pulp of tomatoes, adding value to products in the tomato industry. 


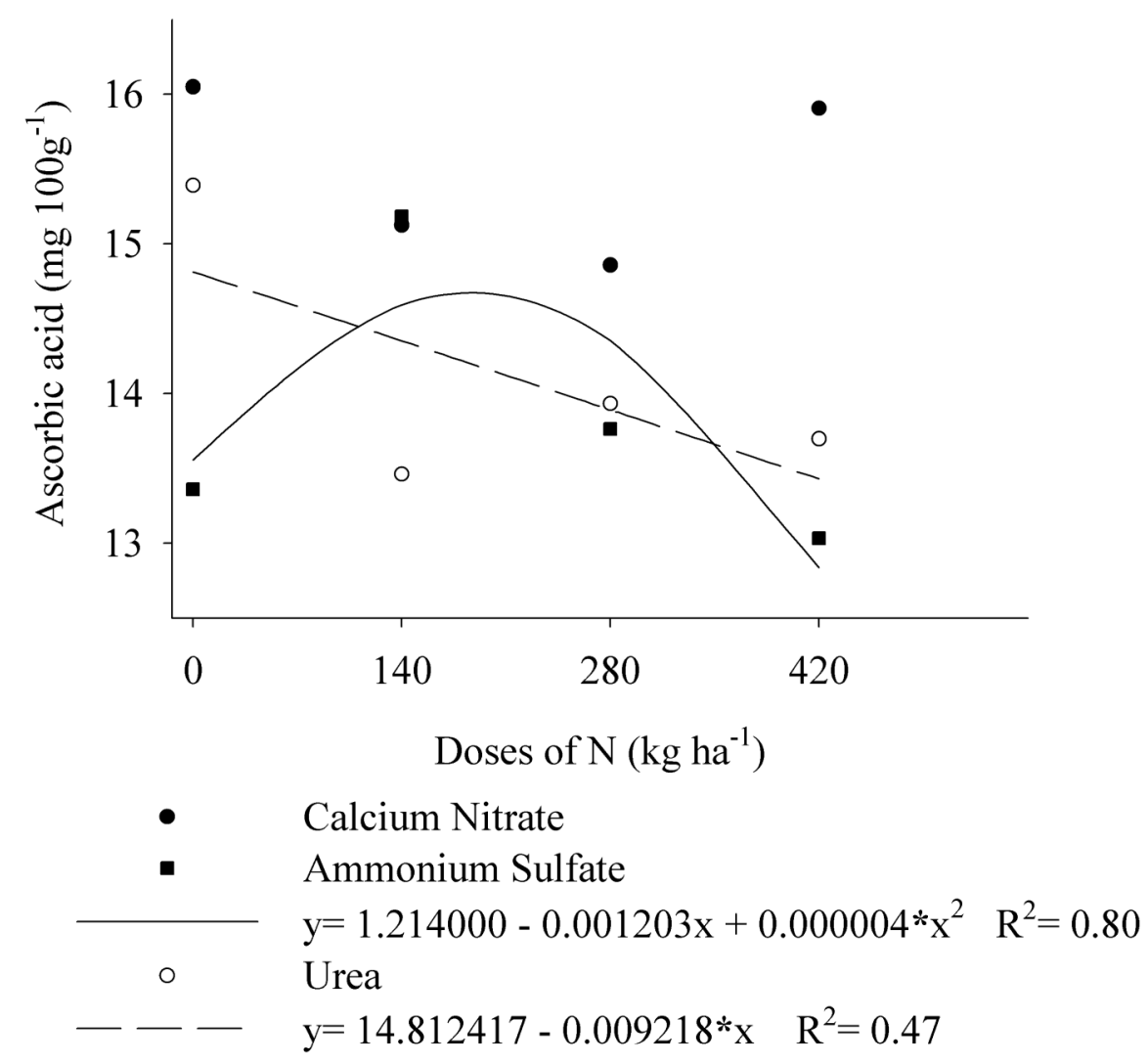

Figure 2. Content of ascorbic acid in fruit of the Silvety tomato hybrid when grown using different sources and doses of N.

The significant reduction of flavonoid content in tomato pulp was due to the increase in doses of $\mathrm{N}$ (Figure 3 B). Bénard et al., (2009) found an increase in the content of rutin present in tomato fruit when the supply of $\mathrm{N}$ was reduced in the plant, demonstrating that $\mathrm{N}$ has an important role in the synthesis of polyphenols and flavonoids.

According to Parr and Bolwell (2000), exposure to light induces production of flavonoids in fruit, which, along with carotenoids, are plant pigments protect the organism from UV located in the tomato peel. Therefore, the increase in $\mathrm{N}$ can lead to increases in shoot biomass, shading the fruit during development and, thus, can reduce the flavonoid content.

The total phenolic compound content was influenced not only by different doses of $\mathrm{N}$ but also by the various $\mathrm{N}$ sources used. The increased levels of $\mathrm{N}$ reduced the phenolic compound content from

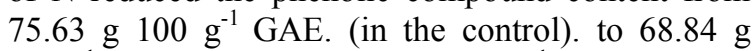
$100 \mathrm{~g}^{-1}$ GAE. at a dose of $420 \mathrm{~kg} \mathrm{ha}^{-1} \mathrm{~N}$ (Figure 4). By reducing $\mathrm{N}$ supply during tomato production, Bénard et al., (2009) found that the content of phenolic compounds slightly increased, confirming the results obtained in this study.
Toor, Heeb and Savage (2006) reported that there was competition between protein synthesis and phenolic compound concentration, as they share a common precursor in their biosynthetic pathways (L-phenylalanine). Therefore, plants with limited supplies of $\mathrm{N}$ and sufficient light to ensure a normal photosynthetic rate, could be involved in additional carbon sequestration during photosynthesis, instead of allocating the surplus for the synthesis of secondary compounds, such as polyphenols.

The change in phenolic compound content in relation to $\mathrm{N}$ dose was similar to that of the flavonoids, thus, they are both affected by the high supply of $\mathrm{N}$ exerts on phenolic compounds is clearly denoted.

Among the sources of $\mathrm{N}$ applied, the greatest influence on phenol content was observed using calcium nitrate in the tomato Silvetty (Table 3). However, Toor, Heeb and Savage (2006), found no significant difference in the content of phenolic compounds in tomato produced with different types of $\mathrm{N}\left(\mathrm{N}-\mathrm{NH}_{4}^{+}\right.$and $\left.\mathrm{N}-\mathrm{NO}_{3}-\right)$. The same authors found that application of high levels of $\mathrm{N}_{-} \mathrm{NH}_{4}^{+}$promoted plant growth by reducing the production of secondary metabolites involved in plant defense and, consequently, reducing antioxidant activity. 

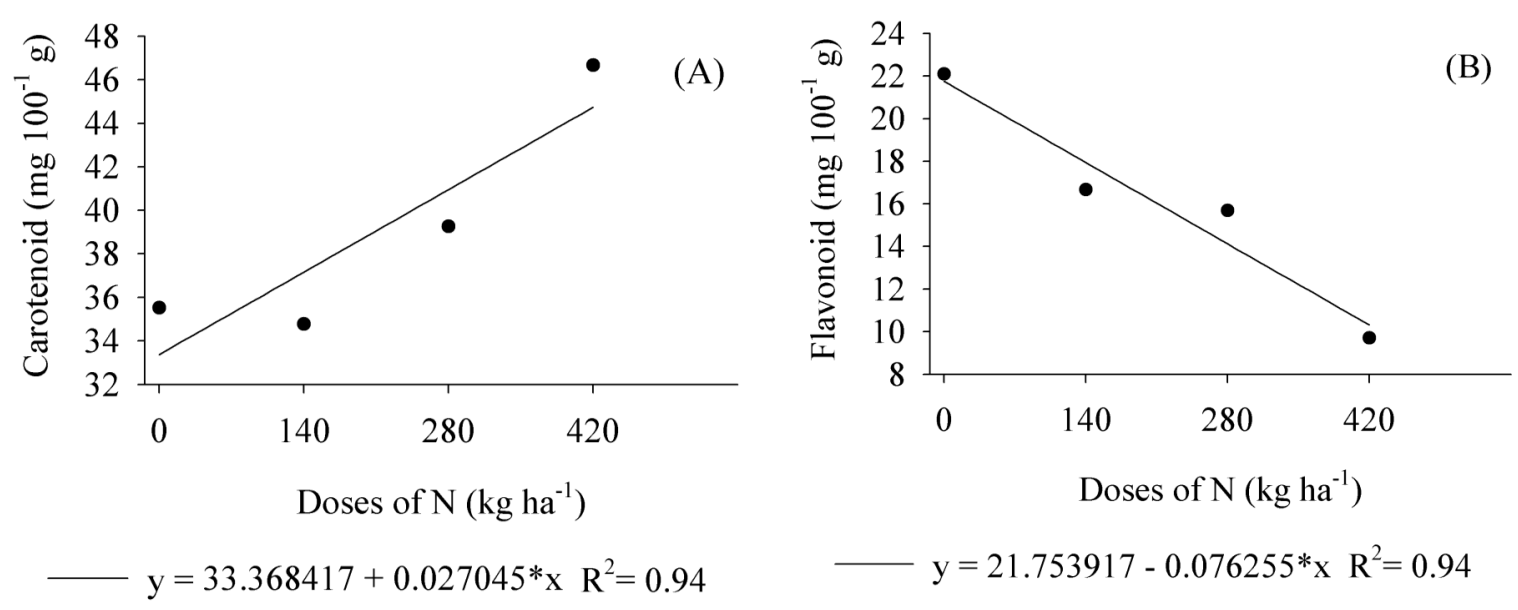

Figure 3. Values of carotenoids (A) e Flavonoids (B) in function of doses of N.

The antioxidant activity in $330 \mathrm{mg} \mathrm{ml}^{-1}$ of tomato in alcoholic extract reduced inhibition of the DPPH free radical from $65.40 \%$ to $40.64 \%$ when the treatments ranged from 0 to $420 \mathrm{~kg} \mathrm{ha}^{-1}$ of $\mathrm{N}$ (Figure 4B). Alternatively, Nunez-Ramirez et al., (2011) found that when analyzing the effect of $\mathrm{N}$ doses in the habanero pepper (Capsicum chinense Jacq.) cv. Naranja grown in an open environment, they found no significant effect of nitrogen fertilization on the antioxidant capacity.

Other authors have found no significant effect of $\mathrm{N}$ in antioxidant activity of other crops, such as melons (FERRANTE et al., 2008) and watercress (KOPSELL et al., 2007). Nevertheless, Ibrahim et al., (2012) have reported the reduction of antioxidant

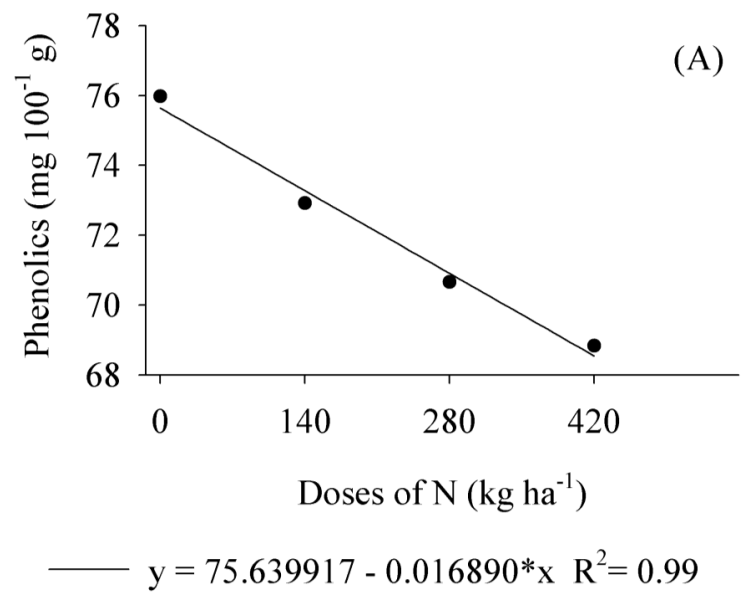

activity of leaves, stems, and roots from a medicinal plant (Labisia pumila Blume) with an increase in $\mathrm{N}$ supply.

Therefore, the decrease in antioxidant activity presented the present study, suggests there is a decrease in antioxidant activity with the supply of $\mathrm{N}$ in tomatoes. The change in antioxidant activity of tomatoes depending on ammonium sulfate concentration was similar to that observed in the content of phenolic compounds. Toor, Savage and Lister (2005) reported that phenolic compounds are the most important contributors to antioxidant activity. However, more research is needed to demonstrate the effect of $\mathrm{N}$ on the antioxidant activity of tomatoes.

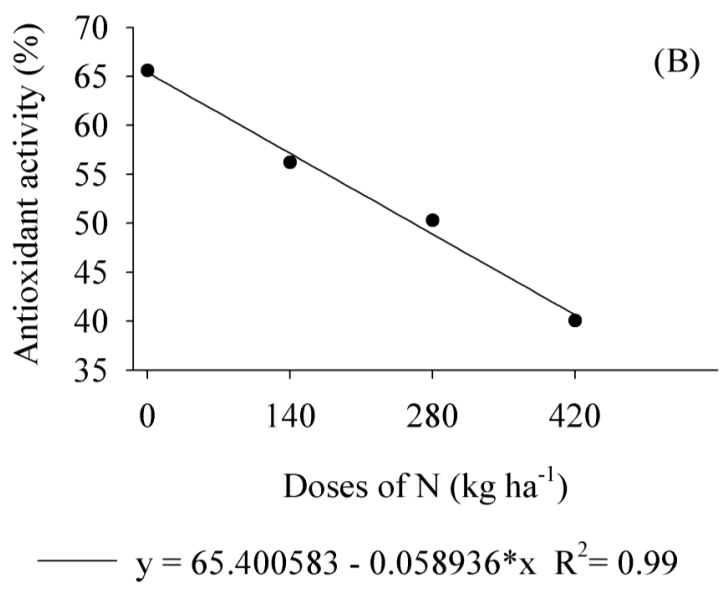

Figure 4. Values of phenolic compounds (A) and antioxidant activity (B) in function of doses of N.

\section{CONCLUSION}

Nitrogen fertilization did not influence tomato fruit firmness or the content of soluble solids. Contrarily, the supply of $\mathrm{N}$ reduced titratable acidity, increasing the SS/TA ratio, changing the flavor of the fruit. The results show that carotenoid content is improved by increasing the doses of applied N. In contrast, the ascorbic acid content, flavonoid concentration, phenolic compound content, and antioxidant activity are reduced, damaging the nutraceutical quality of tomato fruits.

\section{ACKNOWLEDGMENTS}


We would like to thank Coordenação Aperfeiçoamento de Pessoal de Nível Superior (CAPES), for the support provided for this dissertation project.

\section{REFERENCES}

ANZA, M.; RIGA, P.; GARBISU, S. Effects of variety and growth season on the organoleptic and nutritional quality of hydroponically grown tomato. Journal of Food Quality, Nova Jersey, v. 29, n. 1, p. 16-37, 2006.

AWAD, A. M.; DE JAGER, A; VAN WESTING, L. M. Flavonoid and chlorogenic acid levels I Apple fruit: characterizations of variation. Scientia Horticulturae, Filadélfia, v. 83, n. 3, p. 249-263, 2000 .

BÉNARD, C. et al. Effects of low nitrogen supply on tomato (Solanum lycopersicum L.) fruit yield and quality with special emphasis on sugars, acids, ascorbate, carotenoids, and phenolic compounds. Journal of Agricultural and Food Chemistry, Washington, v. 57, n. 10, p. 4112-4123, 2009.

BONDET, V.; BRAND-WILLIAMS, W.; BERSET, C. Kinetics and Mechanisms of Antioxidant Activity using the DPPH Free Radical Method. Lebensmittel -Wissenschaft und-Technologie, Filadélfia, v. 30, n. 6 , p. $609-615,1997$

BORGUINI, R. G. et al. Antioxidant Potential of Tomatoes Cultivated in Organic and Conventional Systems. Brazilian archives of biology and technology, Curitiba, v. 56, n. 4, p. 521-529, 2013

BRAND-WILLIAMS，W.; CUVELIER， M. E.; BERSET, C. Use of a free radical method to evaluate antioxidant activity. Food Science and Technology, Filadélfia, v. 28, n. 1, p. 25-30, 1995.

BRITTO, D. T.; KRONZUCKER, H. J. Nitrogen acquisition, PEP carboxylase, and cellular $\mathrm{pH}$ homeostasis: new views on old paradigms. Plant Cell Environ, Nova Jersey, v. 28, n. 11, p. 13961409, 2005.

DUMAS, Y. et al. Effects of environmental factors and agricultural techniques on antioxidant content of tomatoes. Journal of the Science of Food and Agriculture. Nova Jersey v. 83, n. 5, p. 369-382, 2003.

FERRANTE, A, et al. Effect of nitrogen fertilisation levels on melon fruit quality at the harvest time and during storage. Journal of the Science Food and Agriculture, Nova Jersey, v. 88, n. 4, p. 707-713, 2008.
FERREIRA, D. A. Sisvar: a computer statistical analysis system. Ciências e Agrotecnologia, Lavras, v. 35 , n. 6 , p. 1039-1042, 2011.

FERREIRA, M. M. M. et al. Qualidade do tomate em função de doses de nitrogênio e da adubação orgânica em duas estações. Horticultura Brasileira, Brasília, v. 24, n. 2, p. 141-145, 2006.

FLORES, P. et al. Tomato yield and quality as affected by nitrogen source and salinity. Agronomie, Lyon, v. 23, n. 3, p. 249-256, 2003.

FRITZ, C. et al. Regulation of secondary metabolism by the carbon-nitrogen status in tobacco: nitrate inhibits large sectors of phenylpropanoid metabolism. The Plant Journal, Oxford, v. 46, n. 4, p. 533-548, 2006.

GRAZIANI, G. et al. Effect of peeling and heating on carotenoid content and antioxidant activity of tomato and tomato-virgin oliveoil systems. European Food Research Technology, Heidelberg, v. 216, n. 2, p. 116-121, 2003.

GUIL-GUERRERO, J. L.; REBOLLOSO-FUENTES, M. M. Nutrient composition and antioxidant activity of eight tomato (Lycopersicon esculentum L.) varieties. Journal of Food Composition and Analysis, Filadélfia, v. 22, n. 2, p. 123-129, 2009.

HASSAN, S. A. et al. Nitrate, Ascorbic Acid, Mineral and Antioxidant Activities of Cosmos caudatus in Response to Organic and Mineral-Based Fertilizer Rates. Molecules, Basel, v. 17, n. 7, p. 7843-7853, 2012.

HEEB, A. et al. Nitrogen form affects yield and taste of tomatoes. Journal of the Science Food and Agriculturae, Weinheim, v. 85, n. 8, p. 1405-1414, 2005 .

IBRAHIM, M. H. et al. Involvement of Nitrogen on Flavonoids, Glutathione, Anthocyanin, Ascorbic Acid and Antioxidant Activities of Malaysian Medicinal Plant Labisia pumila Blume (Kacip Fatimah). International Journal of Molecular Science, Basel, v. 13, n. 1, p. 393-408, 2012.

ILAHY, R. et al. Phytochemical composition and antioxidant activity of high-lycopene tomato (Solanum lycopersicumL.) cultivars grown in Southern Italy. Scientia Horticulturae, Filadélfia v. 127, n. 3, p. 255-261, 2011.

JAVANMARDI, J.; KUBOTA, C. Variation of lycopene, antioxidant activity, total soluble solids and weight loss of tomato during postharvest storage. Postharvest Biology and Technology, Filadélfia, v. 
41, n. 2, p. 151-155, 2006.

JONES JUNIOR J. B. Tomato plant culture: in the field, greenhouse and home garden. Florida: CRC Press, 1999, 199 p.

KEMAL, G. M. et al. Changes in phytosterols in rapeseed (Brassica napus L.) and their interaction with nitrogen fertilization. International Journal of Agricultural and Biology, Faisalabad, v. 9, n. 2, p. 250-253, 2007.

KOBRYŃ, J.; HALLMANN, E. The Effect of Nitrogen Fertilization on the Quality of Three Tomato Types Cultivated on Rockwool. Acta Horticulturae, Korbeek, v. 691, n. 1, p. 56-58, 2005.

KOPSELL, D. A. et al. Influence of Nitrogen and Sulfur on Biomass Production and Carotenoid and Glucosinolate Concentrations in Watercress (Nasturtium officinale R. Br.). Journal of Agricultural and Food Chemistry, Washington, v. 55, n. 26, p. 10628-10634, 2007.

KOPSELL, D. A.; KOPSELL, D. E., Accumulation and bioavility of dietary carotenoids in vegetable crops. Trends Plant Science, Cambridge, v. 11, n. 10, p. 499-507, 2006.

MARINHO, C. S. et al. Fontes e doses de nitrogênio e a qualidade dos frutos do mamoeiro. Scientia Agrícola, Piracicaba, v. 58, n. 2, p. 345-348, 2001.

NÚÑEZ-RAMÍREZ, F. et al. Nitrogen fertilization effect on antioxidants compounds in fruits of habanero chili pepper (Capsicum chinense). International of Journal Agricultural and Biology. Faisalabad, v. 13, n. 13, p. 827-830, 2011.

OLIVEIRA, M. N. S. et al. Estádio de maturação dos frutos e fatores relacionados aos aspectos nutritivos e de textura da polpa de pequi (Caryocar brasiliense Camb). Revista Brasileira de Fruticultura, Jaboticabal, v. 28, n. 3, p. 380-386, 2006.

PARR, A. J.; BOLWELL, G. P. Review: Phenols in the plant and in the man. The potential for possible nutritional enhancement of the diet by modifying the phenols content or profile. Journal of Science Food and Agriculture, Weinheim, v. 80, n. 7, p. 985-1012, 2000.

ROCHA, C. B.; SILVA, J. Nota científica: Atividade antioxidante total em tomates produzidos por cultivos orgânico e convencional. Brazillian Journal Food Technology, Campinas, v. 14, n. 1, p. 27-30, 2011.

SCHWARTZ, E. et al. Avaliação de populações de Butia capitata de santa vitória do palmar. Revista
Brasileira de Fruticultura, Jaboticabal, v. 32, n. 3, p. 736-745, 2010.

SIMONNE, A. H. et al. Effects of nitrogen rates on chemical composition of yellow grape tomato grown in a subtropical climate. Journal of Plant Nutrition, Kiel, v. 30, n. 6, p. 927-935, 2007.

STROHECKER, R.; HENNING, H. M. Analisis de vitaminas: métodos comprobados. Madrid: Paz Montolvo, 1967. $428 \mathrm{p}$.

TOOR, R. K.; SAVAGE, G. P.; HEEB, A. Influence of different types of fertilisers on the major antioxidant components of tomatoes. Journal of Food Composition and Analysis, Filadélfia, v. 19, n. 1, p. $20-27,2006$.

WARNER, J.; ZHANG, T. Q.; HAO, X. Effects of nitrogen fertilization on fruit yield and quality of processing tomatoes. Canadian Journal of Plant Science, Ottawa, v. 24, n. 3, p. 865-861, 2004.

WETTASINGHE, M.; SHAHIDI, F. Evening Primrose Meal: A Source of Natural Antioxidants and Scavenger of Hydrogen Peroxide and Oxygen-Derived Free Radicals. Journal of Agricultural and food Chemistry, Davis, v. 47, n. 5, p. 1801-1812, 1999. 